\title{
The Moral Foundations of the Constitution
}

\author{
Tengku Ahmad Hazri*
}

Despite the primacy of Malaysia's written constitution and despite its lofty status as the very foundation of the nation and the embodiment of the social contract, recent trends reveal a shift away from the black letters of the law towards a search for the moral foundations of the constitution, foundations that are largely unwritten.

Significantly, from all sides of the debate the sanctity of the constitution itself has been upheld and, although different parties have advanced different interpretations of its ideals and history, none have gone to the point of challenging its validity. This is interesting, especially with reference to Malaysia, because the constitution itself was drafted by the Reid Commission, comprising five members, none of whom were Malayan. The constitution could have easily been construed as a remnant of neo-colonialism, but this has not happened. At least not so far.

The search for the moral foundations of the constitution has been driven in part by the realisation that as a written law, albeit the supreme law, the constitution is nevertheless vulnerable to change and amendment that could depart significantly from the cherished ideals of the founding fathers and the earliest community. Such change to the constitution can be effectuated with ease by the political party that commands a majority of seats in Parliament, particularly if it wields more than a two thirds majority. Yet to be clear, unlike in other parts of the world, this fear has less to do with concern about an elite few versus an upsurge in populism. This pertinent point explains why the scenario in Malaysia cannot be framed as that of "constitutionalism-versus-democracy", a framework that has been so carelessly applied in analysing political transitions throughout the world. The fear, rather, is that the ruling elite will use the instruments of government at its disposal, such as the re-delineation of electoral constituencies or use of government-linked media, to unfairly promote the ruling political coalition. There is, in other words, no fear that democracy itself would jeopardise the rule of law and constitutionalism. Thus, it can be said that, despite an increase in global cynicism towards democracy with the rise of populism and right-wing nationalism, Malaysia remains optimistic about democracy's role in the service of the rule of law.

To anchor the constitution in a strong moral footing, advocates have sought to look beyond the black letters of the law to situate the constitutional text within a historical and moral context. The eminent constitutional law scholar, Shad 
Saleem Faruqi, aptly words it thus, "A constitution is not mere words written on paper. It is animated by inarticulate values and ideals. It has a spirit and a soul... The constitution's core values are not written in the sands to be washed away by incoming political tides." Such reference to "core values" carries an implicit moral overtone, amplified by recent judicial pronouncements to that effect, as explained below.

The idea that the constitution is underpinned by moral aspirations was recognised early on. Former Lord President (as the Chief Justice was once known), Tun Salleh Abbas, once referred to what he called the "traditional elements" of the Malaysian constitution, namely: (1) the position of Islam as the religion of the Federation; (2) the Malay language as the national language; (3) the position of the sultans and rulers of each state; and (4) the special position of the Malays. With these "traditional elements," Salleh Abbas highlighted the constitution's distinctive identity and foundation for national unity, bringing together the country's diverse communities around shared symbols. Abdul Aziz Bari would later describe these as the "indigenous elements" rather than "traditional" elements.

Following the constitutional crisis of the 1980s, Tunku Abdul Rahman called for a "review of the constitution." What especially worried the Tunku was not only the erosion of the status of the Malay rulers, but more importantly the ease with which the constitution could be amended. He had in mind the amendment which allowed bills to be passed even without the consent of the Yang diPertuan Agong. On 31 August 1984, Tunku wrote, "If we look at the constitution today we find it difficult to lay our hands on any particular subject which has been retained in its original form," and lamented that "the Constitution can be amended as and when the government finds it expedient." Tunku then proposed the establishment of a Royal Commission of Inquiry to review the constitution and make recommendations thereof.

The past few years have witnessed mounting calls for a return to what has been called the "Merdeka Constitution", i.e. the constitution that was adopted when the nation achieved independence (called "Merdeka Day"). This call has been raised by a number of parties. In 1987, prominent constitutional lawyer Tommy Thomas (now the Attorney-General) identified several amendments which "radically altered the basic structure and spirit of the original constitution," namely: (1) the amendment to Article 149 in the 1960s; (2) the 1971 amendment; and (3) the 1973 amendment. Curiously enough, Tommy Thomas made no reference to the 1983 amendment, which removed the powers of the sultans, not counting this amongst the changes that transformed the "basic structure" of the constitution. In 2005, Lim Guan Eng (then Secretary-General of the Democratic Action Party, DAP), in a speech at the Perak DAP State Leadership Retreat, described the 1957 
Merdeka Constitution and the 1963 formation of the Malaysian Constitution as the "driving force towards national unity" and called for its restoration.

These developments have not been confined to the worlds of academia and politics alone. In 2018, the Federal Court, in Indira Gandhi v Pengarah Jabatan Agama Islam Perak, explicitly overturned the thirty-year-old precedent of not recognising the basic structure doctrine in Malaysian law, instead embracing such principles of political morality as the independence of the judiciary, separation of powers and fundamental liberties. The court cited with approval the earlier case of Sivarasa Rasiah v Badan Peguam Malaysia, which affirmed Part II of the constitution on fundamental liberties as part of the basic structure, even though the provision was not originally intended to be part of the constitution, as it was believed to be adequately protected at the legislative level. The earlier Supreme Court case of Loh Kooi Choon v Government of Malaysia (1977), while rejecting the basic structure doctrine, nevertheless acknowledged that the constitution embodies three "basic concepts," namely: (1) the fundamental rights of the individual; (2) the distribution of powers between the Federal and state governments; and (3) the distribution of powers between the executive, judiciary and legislature.

In 2017, yet another attempt was made to infuse the constitution with a moral compass. Given the constitution's lack of a Preamble, an initiative led by, among others, Shad Saleem Faruqi and leading public intellectual, Chandra Muzaffar, sought to advance the Rukunegara (National Charter) as a Preamble to the Federal Constitution. The Rukunegara was adopted by the National Consultative Council (NCC) in the aftermath of the tragic racial riots of 13 May 1969 and proclaimed by the Yang Dipertuan Agong on 31 August 1970. The following year, the prominent intellectual, Syed Hussein Alatas, advanced this very proposal. In his essay, "Rukunegara as the Preamble," Chandra appealed to the perennial values of the Rukunegara, as well as its inclusiveness, as an antidote to the growing communal polarisation in Malaysia that threatens to rupture the fabric of national unity.

More recently, the Sultan of Perak, Sultan Nazrin Shah, has firmly proclaimed the imperativeness of safeguarding the "basic elements" of the constitution and the legitimate interests of all groups. In His Royal Highness' speech at the inauguration of the $14^{\text {th }}$ Perak State Legislative Assembly on 6 August 2018, Sultan Nazrin further emphasised that the "basic elements" were part of the "Merdeka Constitution," which should not be compromised despite the change of government following the $14^{\text {th }}$ General Election. Exactly a week later, on 13 August 2018, the Sultan of Kedah, Sultan Badlishah, when officiating over the $14^{\text {th }}$ Kedah Legislative Assembly, declared that the "traditional elements" of the constitution should be left untouched as they represent the consensus of the diverse communities which represent the social contract. 
These developments demonstrate how, despite the strictest fidelity to the constitution, and despite optimism in its continued role in the life of the nation, there has been a quest to find the moral foundations of this document. From the identification of the "traditional elements" of the constitution, to calls for a return to the Merdeka Constitution and the preservation of the "basic structure" of the constitution, to the initiative to introduce the Rukunegara as the Preamble to the Constitution, there has been a realisation that even the supreme law of the land must ultimately rest on a shared moral framework.

These disparate developments must come together towards a harmonious and equitable solution for all that genuinely reflects the shared moral ethos of all Malaysians.

\section{Notes}

* Tengku Ahmad Hazri is Research Fellow, International Institute of Advanced Islamic Studies (IAIS) Malaysia. He can be contacted at ahmhazri@iais.org. my. 